\section{Producing Woody Floral Products in an Alleycropping System in Nebraska}

\author{
Scott J. Josiah, ${ }^{1}$ Heidi Brott, ${ }^{2}$ \\ and James R. Brandle ${ }^{3}$
}

AdDitIONAL INDEX WORDS. specialty forest products, specialty woody crops, agroforestry, alternative woody crops, woody stems

\section{Summary. Producers in the central United States are showing consider- profitable alternative to using conven- tional woody species.} able interest in growing alternative crops such as specialty forest products for food, herbal medicinal, decorative floral and craft markets. Crops showing particular promise are shrubs and trees that produce decorative woody stems such as curly willow (Salix matsudana), scarlet curls willow ( $S$. matsudana 'Scarlet Curls'), french pussy willow ( $S$. caprea), red twig dogwood (Cornus sericea), and branches of flowering trees and shrubs, including apple (Malus spp.), cherry (Prunus spp.), and forsythia (Forsythia spp.). The objectives of this study were to 1 ) determine yields and performance of 10 woody plant cultivars used in the floral industry, and planted in an alleycropping configuration, and 2) quantify wholesale prices, establishment and maintenance costs, management and harvest labor inputs, and financial returns by cultivar. Production and performance data are derived from a 40-acre (16.2-ha) alleycropping trial in Nebraska containing 10 species or cultivars of shrubs that produce woody florals. Results are based on two harvests that commenced two and three growing seasons after establishment. Harvested woody stem size and quality were measured and determined, and sold to wholesale florists to determine prices and identify buyer requirements.

School of Natural Resource Sciences, 107 Plant Industry Building, University of Nebraska-Lincoln, Lincoln, NE 68583-0814.

A contribution of the University of Nebraska Agricultural Research Division, Lincoln, NE 68583. Journal series 13836. This material is based on work supported by the Cooperative State Research, Education, and Extension Service, U.S. Department of Agriculture, under Agreement No. 99-34292-7388. Any opinions, findings, conclusions, or recommendations expressed in this publication are those of the authors and do not necessarily reflect the view of the U.S. Department of Agriculture.

${ }^{1}$ Assistant professor and state extension forester.

${ }^{2}$ Forest technician.

${ }^{3}$ Professor.
Annual gross financial returns ranged from a high of $\$ 24.94 /$ plant for scarlet curls willow to a low of $\$ 0.63$ / plant for bloodtwig dogwood ( $C$. sanguinea var. atrosanguinea), while net returns per plant for these species ranged from a positive $\$ 17.46$ to a loss of $\$ 1.30$. Financial returns varied among species and cultivars due to the combined effects of annual marketable stem production, harvesting and processing labor requirements, and price/stem. Stem production increased over time due to subsequent coppicing of harvested plants. Overall findings indicate that commercial production of selected cultivars of woody florals in an alleycropping arrangement can be a

S pecialty forest products, derived from trees or shrubs, include products for food, herbal medicinal, decorative floral and craft markets. Species that produce these products can be integrated into agroforestry configurations such as windbreaks, living snow fences, alleycropping arrangements (single rows of trees or shrubs widely spaced within an agricultural field), or riparian forest buffers to improve profitability and system sustainability. These plantings may help to conserve and protect natural resources, and generate income through the production of specialty products. Plants that produce woody floral products are particularly good candidates for use in agroforestry systems because of their substantial markets, rapid growth, ease of integration into agricultural fields, and off-season labor requirements,

Any woody species that has a colorful or unusually shaped stem, bud, flower, or bark can become a decorative woody floral product (Armitage, 1993; Stevens, 1998; Sturdivant, 1996). Plants that produce woody floral products (hereafter referred to as woody florals), including species such as curly or corkscrew willow, scarlet curls willow, pussy or goat willow, red twig dogwood, and branches of flowering trees and shrubs, including apple, cherry, and forsythia, among others are used extensively by North American floral designers to enhance floral arrangements. These woody species add interesting colors, textures, or form to floral arrangements, increase their width and height, and enhance profit margins.

Little formal research has been conducted to specifically determine woody floral cultivation practices, their performance in agroforestry systems, or the financial and economic benefits of these species. Smith (1929) described the general economic potential of producing specialty forest products on marginal cropland. Douglas and Hart (1984) described potential tree/crop assemblages in various agricultural systems worldwide. Robles-Diaz-de-Leon (1997) conducted a theoretical appraisal of the production of specialty forest products (including woody florals) in riparian zones, reporting theoretical annual gross returns of $\$ 24,282$ /acre (\$60,000/ha), although the financial analysis methods used to determine these returns were not reported. Miller et al. (1994) selectively harvested 84 marketable pussy willow branches $>23$ inches $(58.4 \mathrm{~cm})$ per plant, two growing seasons after planting in a riparian forest buffer in Indiana. Gross annual financial returns of up to $\$ 13,590 /$ acre $(\$ 33,580 /$ ha $)$ were estimated from a range of specialty forest products that included woody florals.

This paper reports on recent findings from woody decorative floral cultivar field trials, production research, and exploratory product sales in Nebraska. Objectives of this study included 1) determining marketable yields and performance of 10 cultivars of woody plants used in the floral industry and planted in an alleycropping configuration and 2) quantifying wholesale prices, establishment and maintenance costs, management and harvest labor inputs, and financial returns by cultivar.

\section{Materials and methods}

To develop realistic production information for woody florals in agroforestry systems, a 40-acre flatland alleycropping research/demonstration trial was installed in May 1999 at the University of Nebraska's Agricultural Research and Development Center near Mead, Nebr. [lat. 41 '29'N, long. 96³0' $\mathrm{W}$, elevation $1161 \mathrm{ft}(354 \mathrm{~m})]$, USDA Hardiness Zone 4b. This trial included 30 species of trees and shrubs that produce commercially valuable specialty woody crops such as nuts, fruit, herbal medicinal, and woody floral products. Ten of the thirty species or cultivars in this trial produce woody floral products (Table 1). Woody plants were purchased from wholesale nurseries in Minnesota, Iowa, Missouri and Montana. For the species and cultivars reported on in this paper, 2 to $3 \mathrm{ft}(0.6$ to $0.9 \mathrm{~m})$ tall nurs- 
ery stock were planted in $10 \mathrm{ft}(3.0 \mathrm{~m})$ wide rows spaced $60 \mathrm{ft}(18.3 \mathrm{~m})$ apart in two widely separated agricultural fields where corn, soybeans and wheat are produced in rotations between the rows. Woody plants were spaced $5 \mathrm{ft}(1.5$ $\mathrm{m}$ ) apart within the rows. Five woody plants per cultivar per plot were repeated 10 times (totaling 50 plants per species or cultivar) in a randomized complete block design. Replicates were randomly distributed in the rows (five replicates in each field), but blocked with respect to adjacent windbreaks.

Annual precipitation totaled 31.2 inches $(792 \mathrm{~mm})$ in $1999,23.6$ inches $(599 \mathrm{~mm})$ in 2000 and 25.6 inches $(650$ $\mathrm{mm}$ ) in 2001 . The normal 30 -year average annual precipitation is 27.8 inches $(706 \mathrm{~mm})$. No supplemental irrigation was provided. The woody plants in this study likely benefited from annual applications of manure or commercial fertilizers to adjacent row crops, but fertilizer was not directly applied to the shrubs.

Woody florals were grown for two seasons (2 years) to permit shrubs to establish and were then harvested with hand loppers. Quantity, length (tips, mediums, and longs with the length of each varying by market criteria for each species or cultivar) and condition (color, lack of defects - browse damage, dead tips, scarred stems, excessive branching, etc.) of harvested woody stems of each species or cultivar were measured and determined. Second-year production was harvested in February to Mar. 2001 , measured, and given to wholesale and retail florists for their evaluation and feedback regarding product quality and acceptability. Third-year production was harvested, measured and sold to wholesale florists in Nebraska during November to December 2001. Times required for maintenance, cultivation, harvesting, grading and marketing also were recorded.

Estimated establishment costs were derived from current cost figures of Nebraska Natural Resource Districts (NRD) providing tree-planting services. Costs were adjusted for the slightly higher seedling costs for shrub liner stock [ $1 \mathrm{ft}(30.5 \mathrm{~cm})$ or shorter] available from commercial nurseries in the central U.S. While larger and more expensive nursery stock was used to establish this trial, smaller stock is avail- able and would more likely be used by landowners interested in establishing commercial plantings. Establishment costs included site preparation (tillage), two herbicide applications/year for weed control, plant material costs [for small 8 to 12 inch $(20.3$ to $30.5 \mathrm{~cm}$ ) nursery liner stock], and planting costs (including replacing 20\% mortality in the second year, an estimate commonly used by NRDs in Nebraska).

\section{Results and discussion}

Production trials. First and second harvest results are reported in Table 1. Estimates of numbers of marketable stems per $1000 \mathrm{ft}(304.8 \mathrm{~m})$ and per 1 acre $(0.4 \mathrm{ha})$ were derived from average marketable stems per plant data after the second harvest and adjusted in-row spacings by cultivar or species. We used adjusted in-row spacing distances for production estimates because measured plant widths indicated either that closer or wider spacings were more appropriate, depending on species or cultivar, than the 5 - $\mathrm{ft}$ spacing used in the trail. Based on consultation with retail and wholesale florists in 2001, we determined a marketable stem was $3 \mathrm{ft}$

Table 1. Average and estimated number of marketable woody floral stems in Nebraska at first harvest (February to March 2001) and second harvest (November to December 2001).

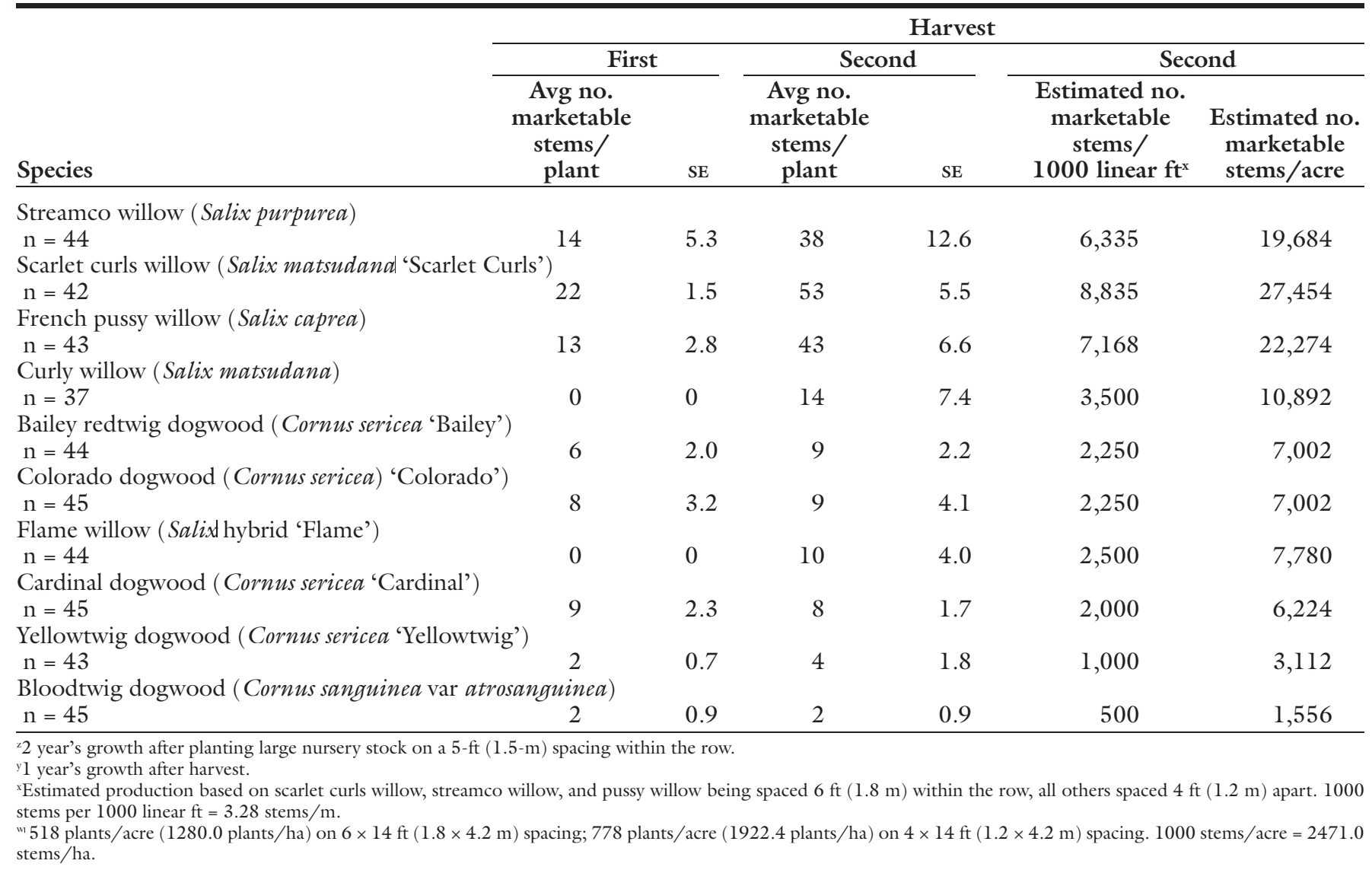


or longer, with little deer browse, freeze or physical damage, and good color (as applicable). Harvested woody floral stems were cut between 2 and 6 inches $(5.1$ to $15.2 \mathrm{~cm}$ ) from the ground. This was done to simulate commercial production practices in which all stems would be mechanically harvested, and to stimulate greater coppicing and stem numbers.

Subsequent to these harvests, several growers interviewed indicated that they only cut marketable stems, reducing subsequent grading activities. Cutting all stems may be an appropriate management practice for some species (pussy, curly, and scarlet curls willows) for which most stems per plant grow 5 $\mathrm{ft}$ or more in height in 1 year, thus producing higher numbers of marketable stems. However, a large percentage of harvested dogwood and flame willow stems were only 1 to $3 \mathrm{ft}$ tall after 1 year's growth and were discarded as being unmarketable, significantly reducing potential financial returns. Alternative management practices for these species which need to be evaluated in the future include selectively harvesting only marketable stems after one growing season, harvesting entire plants after 2 years, or accelerating height growth with irrigation and fertilization.

Because the first harvest occurred from February to March 2001, whitetailed deer (Odocoileusvirginianus) had unlimited access to these plots during most of the winter, resulting in high levels of browse and rub damage. Deer browse damage was especially severe on several dogwood cultivars, causing rejection of $50 \%$ or more of the stems. Several of the willow species [scarlet curls, flame, streamco (Salix purpurea)] experienced little browse damage during this period (S. Hygnstrom and S.J. Josiah, unpublished). Browse damage was better managed during the winter of 2001-02 by harvesting the most susceptible species in November and December before cumulative deer browse damage could reach severe levels. Dogwoods left to grow l year after being browsed produced bifurcated stems, but this did not affect market value or salability. Goldencurl willow (Salix alba var. tristis $\mathrm{x}$ S. matsudana) and corkscrew willow, both upright cultivars, experienced severe rubbing damage both winters. Three years after establishment, goldencurl willow was still a poor performer with low vigor, high mortality, and few marketable stems.

Shrubs responded well to cutting to the ground each winter, producing high numbers of 2 to $8 \mathrm{ft}$ ( 0.6 to 2.4 $\mathrm{m})$ tall stems the following growing season, depending on species. Scarlet curls, streamco and pussy willows all produced prolific numbers of stems. Streamco willow is not commonly marketed as a woody floral, though it may have potential due to its flexibility, green/purple stem color, and small pussy willow-type buds. Yellowtwig dogwood (Cornussericea 'Yellowtwig') was shortest after 1 year's growth (2 to $3 \mathrm{ft}$ ) while scarlet curls willow was the most vigorous and tallest $[7 \mathrm{ft}(2.1 \mathrm{~m})]$. Yields of marketable stems increased, sometimes substantially, between first and second harvests. This was largely due to extensive coppicing of shrubs after the first cutting. It is not yet known whether and to what degree this trend toward increasing numbers of stems/plant after each harvest will continue. Yields shown in Table 1 are somewhat lower than those of Miller et al. (1994). Higher yields could be due to greater moisture availability and nutrient concentrations in riparian zones as compared to nonirrigated upland areas, or inclusion of shorter stem lengths as marketable. Miller et al., 1994 did not report criteria used to determine marketability.

Some variability between plots in marketable stem yields was observed with many species especially after the first 2 years of growth (Table 1 ). Microsite differences, differential size of nursery stock, and variable plant establishment success all contributed to this variability. In most cases, variability between plots declined as plants became more established. Within plot variability was not measured as individual plant yields were aggregated at the plot level and used as the measurement unit.

Early indications for the 2002 growing season indicated that severe drought conditions, combined with heavy grasshopper (Melanoplus spp.) feeding, significantly reduced stem height and quality. Other pest damage was not important, with minor defoliation caused by larvae of the red spotted purple butterfly (Linenitis basilarchia) and the smartweed caterpillar (Acronieta oblinata).

LABOR REQUIREMENTS AND FINANCIAL RETURNS. Woody florals harvested in late 2001 were sold to three floral wholesalers in Lincoln and Omaha, Nebr., at 2001-02 wholesale market prices (Table 2). Wholesalers were interviewed during deliveries to assess market characteristics and trends, and product quality criteria.

Producing woody florals requires relatively intensive labor inputs during four distinct periods: plantation establishment, harvest, processing, and marketing. Since all activities except plantation establishment (which is usually done in the spring) occur during the late fall and winter when stem color peaks, leaves have dropped, and after agricultural producers harvest their conventional crops, potential labor availability conflicts are reduced.

Establishment costs over 2 years generally range between $\$ 370$ and $\$ 470$ per 1000 linear $\mathrm{ft}(\$ 1.21 / \mathrm{m}$ and $\$ 1.54 /$ $\mathrm{m}$ ) of planting (Table 3). Annual weed control costs in subsequent years total about $\$ 40$ per 1000 linear $\mathrm{ft}(\$ 0.13 / \mathrm{m})$. Because neither supplemental irrigation nor fertilization were used in this study, these costs could not be included in this analysis.

Harvesting, processing and marketing labor requirements were monitored and recorded by species during the November to December 2001 harvest (Table 4). Marketing included phone calls, travel to wholesale florists for initial

Table 2. Prices paid by Nebraska wholesale florists for woody floral stems, by stem size and species or cultivar.

\begin{tabular}{|c|c|c|c|c|c|c|c|c|c|c|}
\hline $\begin{array}{l}\text { Stem } \\
\text { Size }\end{array}$ & \multicolumn{10}{|c|}{ Wholesale prices by stem $(\$)$} \\
\hline Tips: $1.5-3 \mathrm{ft}(0.46-0.9 \mathrm{~m})$ & 0.10 & 0.10 & 0.00 & 0.00 & 0.10 & 0.00 & 0.00 & 0.00 & 0.00 & 0.00 \\
\hline Medium: $3-5 \mathrm{ft}(0.9-1.5 \mathrm{~m})$ & 0.45 & 0.45 & 0.30 & 0.30 & 0.25 & 0.45 & 0.30 & 0.30 & 0.30 & 0.30 \\
\hline Long: $>5 \mathrm{ft}(1.5 \mathrm{~m})$ & 1.50 & 1.50 & 0.30 & 0.30 & 0.25 & 0.45 & 0.30 & 0.30 & 0.30 & 0.30 \\
\hline
\end{tabular}


Table 3. Costs to establish and maintain 1000 linear $\mathrm{ft}(304.8 \mathrm{~m})$ of woody floral-producing plants.

\begin{tabular}{|c|c|c|c|}
\hline $\begin{array}{l}\text { Cost } \\
\text { item }\end{array}$ & $\begin{array}{c}\text { Unit } \\
\text { cost }(\$)\end{array}$ & $\begin{array}{c}\text { Total cost }(\$) \\
\text { at } 6-\mathrm{ft}(1.8-\mathrm{m}) \\
\text { spacing }^{\mathrm{z}}\end{array}$ & $\begin{array}{c}\text { Total cost }(\$) \\
\text { at } 4-\mathrm{ft}^{(1.2-\mathrm{m})} \\
\text { spacing }^{\mathrm{y}}\end{array}$ \\
\hline \multicolumn{4}{|l|}{ Year l costs (establishment year) } \\
\hline Planting costs per plant & 0.30 & 50 & 75 \\
\hline Plant material costs per plant & 0.70 & 117 & 175 \\
\hline Weed control: three herbicide applications/year at $\$ 0.02 / \mathrm{ft}(\$ 0.066 / \mathrm{m})$ & 0.02 & 60 & 60 \\
\hline Replacement of mortality $(20 \%)$ (plant material + planting cost) & & 33 & $\$ 0$ \\
\hline Weed control: three herbicide applications/year at $\$ 0.02 / \mathrm{ft}$ & 0.02 & 60 & 60 \\
\hline Total cost & & 93 & 110 \\
\hline Total establishment costs, years 1 and 2 & & 370 & 470 \\
\hline \multicolumn{4}{|l|}{ Year 3 and thereafter } \\
\hline Weed control: two herbicide applications/year at $\$ 0.02 / \mathrm{ft}$ & 0.02 & 40 & 40 \\
\hline
\end{tabular}

${ }^{2} 167$ plants $/ 1000$ linear $\mathrm{ft}(0.55$ plants $/ \mathrm{m})$.

y250 plants/1000 linear $\mathrm{ft}(0.82$ plants $/ \mathrm{m})$.

Table 4. Woody floral processing and marketing labor requirements and costs, with estimated financial returns per plant, based on second harvest-2001 production.

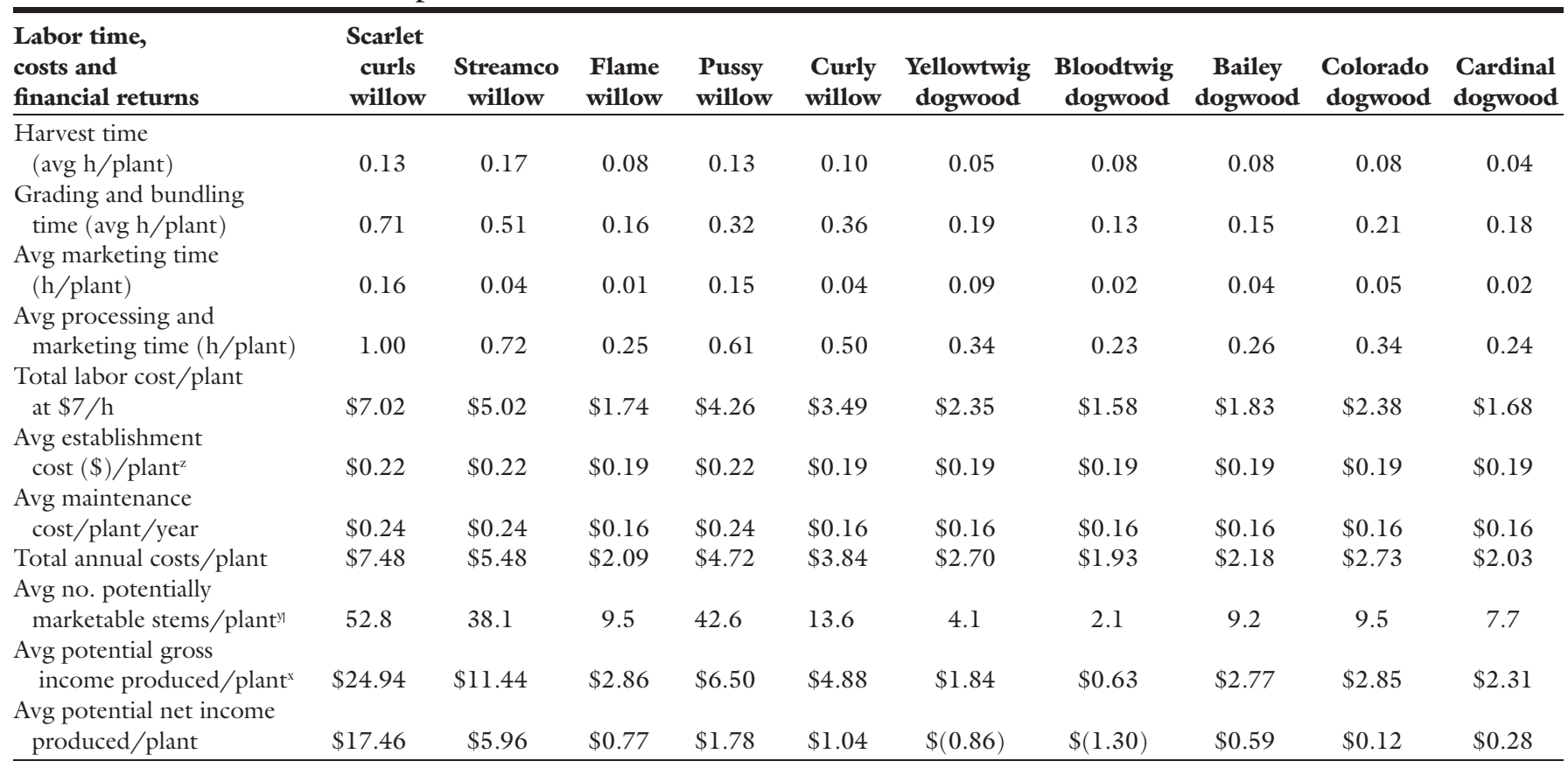

${ }^{2}$ From Table 3 . Total establishment costs after two growing seasons, divided by number of plants per 1000 - $\mathrm{ft}$ ( $\left.304.8 \mathrm{~m}\right)$ row, divided by an assumed 10 -year lifespan of the plant. Scarlet curls, streamco, and pussy willow at 6 - $\mathrm{ft}(1.8 \mathrm{~m})$ in-row spacing, all others at 4 - $\mathrm{ft}(1.2 \mathrm{~m})$ in-row spacing. Average maintenance costs use the same calculation based on third and subsequent year maintenance costs (see Table 3 ).

${ }^{y}$ From Table 1 , second harvest data. Average number of marketable stems for scarlet curls willow, corkscrew willow, and pussy willow include 1.5 - to 5 -ft-long $(0.5-1.5 \mathrm{~m})$ stems. With all other species, the average number of marketable stems include 3 - to 5 - $\mathrm{ft}(0.9-1.5 \mathrm{~m})$ stems only.

xAverage gross income produced per plant is based on average number of marketable stems produced per plant of different size categories and average wholesale value received or estimated for each size category. Prices vary depending on supply, demand, and quality. Specifically for each cultivar or species, average gross income/plant $=$ (no. tips) (price/tip) + (no. mediums) (price/medium) + (no. longs) (price/long).

sales calls and product demonstrations, follow-up phone calls and deliveries. Gross and net income are reported in Table 4 by plant for each species or cultivar. A combination of higher prices per stem, more salable size classes (tips, medium and large stems) and higher production rates of marketable stems per shrub provided high net returns (approaching $\$ 17.50 /$ plant) from scarlet curls willow. Returns were considerably less, though still positive, for pussy willow and corkscrew willow. This was largely due to the lower wholesale price per stem $(\$ 0.25 /$ stem for pussy willow), and relatively slow establishment and subsequent low production rates of curly willow, at least in initial years. Dogwoods were least profitable because plants were harvested prematurely, resulting in a low number of marketable stems, extensive deer browse damage, and relatively low price/stem (usually \$0.30).
Clearly, financial returns from integrated plantings using woody florals in alleycropping systems can be substantial. In addition to the income generated by producing annual crops between woody rows, additional annual income is generated through the sale of woody florals within the row. For instance, extrapolating from production data obtained 3 years after planting, the most productive species with excellent markets (scarlet curls willow) produced 
an estimated net income of $\$ 2.91 /$ linear $\mathrm{ft}(\$ 9.55 / \mathrm{m})$ of planting along a single row [plants spaced $6 \mathrm{ft}(1.8 \mathrm{~m})$ apart within the row] or $\$ 9,282$ /acre $(\$ 22,936 / \mathrm{ha})$ if planted on a 6 by 14 $\mathrm{ft}(1.8 \times 4.3 \mathrm{~m})$ spacing. Average yields and returns of conventional annual crops from these fields are $190 \mathrm{bu} / \mathrm{acre}$ $\left(12,065 \mathrm{~kg} \cdot \mathrm{ha}^{-1}\right)$ for corn (Zea mays) and $55 \mathrm{bu} /$ acre $\left(3,740 \mathrm{~kg} \cdot \mathrm{ha}^{-1}\right)$ for soybeans (Glycine max), grossing \$475/acre ( $\$ 1187.50 / \mathrm{ha}$ ) at $\$ 2.50 / \mathrm{bu}$ for corn or $\$ 302.50 /$ acre $(\$ 756.24 / \mathrm{ha})$ at $\$ 5.50 /$ bu for soybeans (J. Brandle, personal communication).

Experimental field trials, florist interviews, and participation in the marketplace have generated considerable data on the selection, performance, and profitability of woody floral production. These data show that a market-driven natural resource conservation approach based on commercial production of woody florals may be a profitable alternative to using conventional species in alleycropping and potentially other linear agroforestry systems.

\section{Literature cited}

Armitage, A.M. 1993. Specialty cut flowers. Varsity Press, Portland, Ore.

Douglas, J.S. and R.A. de J Hart. 1984. Forest farming. Intermediate Tech. Publ., Exeter, U.K.

Miller, B.K., B.C. Moser, K.D. Johnson, and R.K. Swihart. 1994. Designs for windbreaks and vegetative filterstrips that increase wildlife habitat and provide income. Proc. $2^{\text {nd }}$ Conf. Environ. Sound Agr. p. 567-574. Amer. Soc. Agr. Eng., Orlando, Fla.

Robles-Diaz-de-Leon, L.F. 1997. Evaluation of economic gains from nontimber products in a riparian forest in the Chesapeake Bay watershed. Proc. $5^{\text {th }} \mathrm{N}$. Amer. Conf. Agrofor. (abstr.). p. 82-87. Assn. Temperate Agrofor., Ithaca, N.Y.

Smith, J.R. 1929. Tree crops: A permanent agriculture. Harcourt Brace, New York.

Stevens, A.B. 1998. Field grown cut flowers: A practical guide and sourcebook. Avatar's World, Edgerton, Wis.

Sturdivant, L. 1996. Flowers for sale: Growing and marketing cut flowers-Backyard to acreage. San Juan Naturals, Friday Harbor, Wash. 